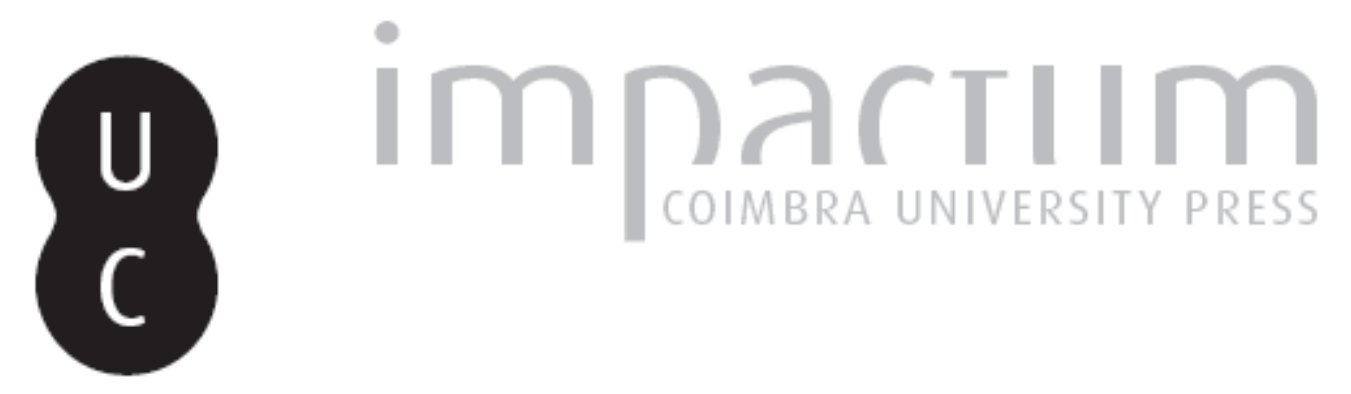

\title{
Antero e a arte
}

Autor(es): $\quad$ Santos, Leonel Ribeiro dos

Publicado por: Imprensa da Universidade de Coimbra

URL persistente:

URI:http://hdl.handle.net/10316.2/43742

DOI:

DOI:https://doi.org/10.14195/2183-8925_13_5

Accessed : $\quad$ 26-Apr-2023 11:05:09

A navegação consulta e descarregamento dos títulos inseridos nas Bibliotecas Digitais UC Digitalis, UC Pombalina e UC Impactum, pressupõem a aceitação plena e sem reservas dos Termos e Condições de Uso destas Bibliotecas Digitais, disponíveis em https://digitalis.uc.pt/pt-pt/termos.

Conforme exposto nos referidos Termos e Condições de Uso, o descarregamento de títulos de acesso restrito requer uma licença válida de autorização devendo o utilizador aceder ao(s) documento(s) a partir de um endereço de IP da instituição detentora da supramencionada licença.

Ao utilizador é apenas permitido o descarregamento para uso pessoal, pelo que o emprego do(s) título(s) descarregado(s) para outro fim, designadamente comercial, carece de autorização do respetivo autor ou editor da obra.

Na medida em que todas as obras da UC Digitalis se encontram protegidas pelo Código do Direito de Autor e Direitos Conexos e demais legislação aplicável, toda a cópia, parcial ou total, deste documento, nos casos em que é legalmente admitida, deverá conter ou fazer-se acompanhar por este aviso.

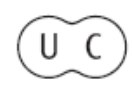


REVISTA DE HISTÓRIA DAS IDEIAS 13

\section{Antero de Quental}

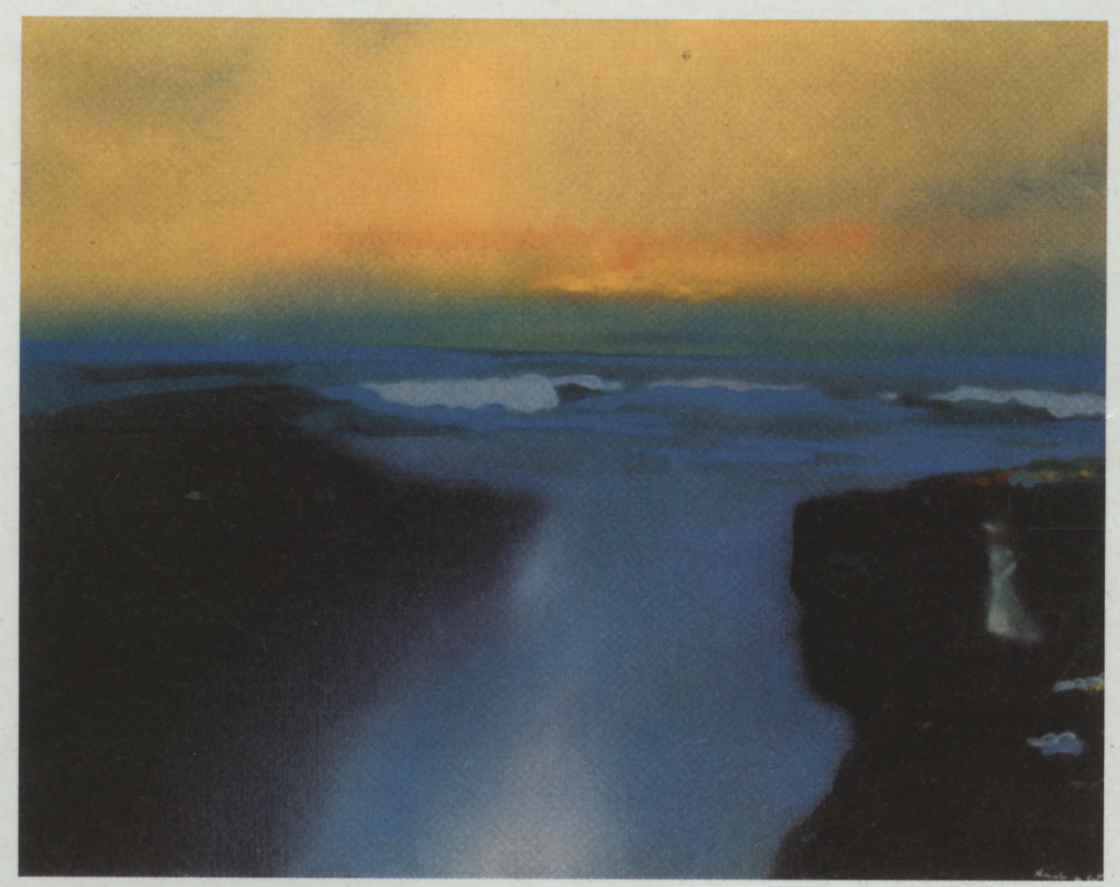

INSTITUTO DE HISTÓRIA E TEORIA DAS IDEIAS FACULDADE DE LETRAS

COIMBRA 1991 


\section{ANTERO E A ARTE}

"Tornou-se manifesto que tudo o que diz respeito à arte deixou de ser evidente."

Theodor W. Adorno, Teoria Estética.

\section{Mais do que uma "aesthetica in nuce"}

Há nas Prosas de Antero um conjunto de pequenos ensaios que ainda não mereceram a devida atenção dos anterianistas.

Bem conhecidas de todos são as peças que desencadearam a "Questão Coimbrã" - Bom senso e bom gosto, A dignidade das letras e as literaturas oficiais, ou a Nota final das Odes Modernas "Sobre a missão revolucionária da poesia". Mas que dizer de outros ensaios como Arte e Verdade, O futuro da música, Tendências novas da poesia contemporânea, Considerações sobre a filosofia da história literária portuguesa, A poesia na actualidade?

Os que se propõem captar os contornos da filosofia de Antero, tão abundantemente prometida - e delineada até - nas suas cartas, mas tão pouco efectivamente expressa e cumprida, deixam esses ensaios para os historiadores e críticos da literatura. Estes, por seu turno, geralmente avessos às ideias e ao teor e âmbito de reflexão que aqueles escritos exigem, passam-lhes ao lado, ou tomam deles apenas os aspectos de circunstância que podem documentar a abordagem das intrigas literárias caseiras da época.

\footnotetext{
* Faculdade de Letras da Universidade de Lisboa.
} 
É desse conjunto de escritos que me ocuparei aqui, esperando contribuir um pouco para o melhor conhecimento do pensamento estético e filosófico de Antero.

Apontarei três razões que me levam a chamar a atenção para esses escritos.

Em primeiro lugar, eles revelam a persistência de uma questão maior entre as que ocuparam as "ruminações" de Antero. De facto, a reflexão anteriana sobre a arte (a poesia, a literatura, a música) impõe-se pela recorrência e pela consistência, pela tensa dialéctica que a sustenta e pela evolução interna que manifesta, tudo o que a torna um incontornável tópico para quem deseje abordar o pensamento do poeta micaelense.

Muito raramente os escritores e poetas portugueses alcançam o plano de uma meditação acerca dos pressupostos do seu ofício, ou chegam ao ponto de o dimensionarem no contexto de uma explícita visão geral do mundo. Sob esse aspecto, o caso de Antero é, no panorama da literatura portuguesa, quase singular. Nunca ele dissociou o plano da criação poética do plano da reflexão filosófica. Pelo contrário, segundo dizia, "a ideia poética sai tanto mais abundante e livre quanto mais clara e lógica é a ideia filosófica" ${ }^{1}{ }^{1}$. A sua condição e labor de poeta é, de facto, secundada por uma reiterada meditação acerca da essência e da função social e civilizadora da poesia e da arte, acerca, enfìm, da significação da arte para a consciência moderna, no contexto de uma explícita filosofia da história. Há em Antero muito mais do que uma aesthetica in nuce. Há a inscrição efectiva da arte numa visão geral do mundo.

Épor isso que o acompanhamento dos passos essenciais da meditação anteriana sobre a poesia e a arte se reveste de particular importância se pretendermos ter acesso ao atelier do poeta, se quisermos compreendê-lo nas motivações da sua obra, nas tensões que o moldaram como pensador e como homem. Ele bem sabia, aliás, que a literatura só pode ser bem compreendida quando é objecto de um olhar filosófico, isto é, quando, para além das formas e produtos literários, se procura toda a alma - "o sentir íntimo" - que os anima $\left(^{2}\right)$.

(') Antero de Quental, Cartas I, organização, introd. e notas de Ana Maria Almeida Martins, Lisboa, Editorial Comunicação, 1989, p. 273.

${ }^{2}$ ) Antero de Quental, Considerações sobre a filosofia da história literária portuguesa, Prosas II, Coimbra, Imprensa da Universidade, 1926, p. 210. 
A segunda razão: a atenção a este aspecto permite, antes de mais, identificar algumas das matrizes de inspiração que desde cedo moldaram o pensamento de Antero, bebidas talvez em "leituras caóticas", como ele mesmo reconhece na carta a Wilhelm Storck, mas não por isso menos decisivas, por escasso que fosse o valor que o pensador atribuía aos seus escritos teóricos da juventude $\left({ }^{3}\right)$. Mais do que isso. Conduzidos pelas reflexões do poeta, somos levados a fazer um interessante balanço da vasta reflexão moderna sobre a arte e a estética. Antero teve consciência muito clara do que a arte e a reflexão sobre ela (chama-se Estética ou Filosofia da Arte) representaram para o pensamento moderno, desde a Aufklärung até ao realismo de inspiração mais ou menos positivista e historicista, dominante na sua época, passando pelo classicismo, pelo romantismo e idealismo. Ele compreendeu a estreitíssima solidariedade que existe entre estética e modernidade, entendida esta como projecto filosófico e cultural. A arte e a estética não são, com efeito, apenas um dos domínios de que se ocupam os filósofos, cada vez com maior intensidade, a partir de meados do século XVIII. Com Baumgarten (Aesthetica, 1750) e seus discípulos, a estética reivindica para si um vasto campo de produtos e de sentimentos sobre os quais não têm jurisdição nem a ciência nem a moral, autonomiza-se e elabora os seus próprios princípios e critérios - a sua lógica específica. No final do século, a arte vê mesmo reconhecida a sua hegemonia entre as formas superiores de expressão e afirmação do espírito humano, hegemonia que só virá a ser contestada mais tarde, primeiro, com a estética hegeliana e, depois, com as estéticas de cariz positivista. Antes, porém, que tal viesse a acontecer, a arte viu-se reconhecida como realização da harmonia das faculdades do espírito (Kant), como promessa e primícia da libertação eemancipação humanas (Schiller), como organon da própria filosofia (Schelling). Perscrutou-se nela, enfim, a originária revelação da natureza e do absoluto (Wackenroder). Sucessivas gerações de pensadores projectaram nela os seus desejos de reconciliação do homem consigo mesmo, os seus projectos de emancipação política, os seus sonhos de desenvolvimento harmonioso de todas as potências anímicas do homem. Na sua meditação sobre a arte Antero recapitula este amplo movimento de aspirações e de reflexões. Também para ele a arte surgiu como uma nova religião

(3) Carta a W. Storck, Cartas II, p. 836. 
capaz de salvar os valores essenciais, como um refúgio contra o cepticismo que lhe corroía o espírito. Assim o confessava a um amigo, numa carta de 7 de Agosto de 1861: "A arte (...) parece-me a mim que já em bem pouco tenho crenças, a única coisa capaz de ainda poder fazer saltar nos peitos todos os corações capazes de nobremente baterem por alguma coisa boa e bela. (...) Quem crê na Arte crê no belo, no bom, isto é, no Amor e em Deus, e com estes elementos pode tudo perder-se mil vezes mil, que mil vezes será tudo salvo. É por isso que tantas esperanças ponho na Arte; $e$ já um culto antecipado da religião que ainda está por nascer para uma sociedade que só por aqui terão alguns uma vaga intuição. Desses alguns quero eu ser" ${ }^{4}$ ).

Uma terceira razão. A leitura do conjunto de ensaios que referimos permite acompanhar a evolução interior do pensamento de Antero num ponto particularmente sensível: aquele que constituiu a sua forma peculiar de expressão e de criação, aquele em que o seu destino e a sua realização estavam directamente comprometidos. Pensar a essência e o destino da arte e da poesia não era para ele mera questão académica. Era uma questão vital. Significava a coragem de pôr em causa a sua própria condição e todo o sentido e valor da sua obra como poeta e ate como homem. Se o soubermos acompanhar nesse esforço, talvez ele nos indique como a sua poesia se inscreve mais fundo no poema (ou drama) da sua existência pessoal, e como este, ainda por sua vez, se liga ao poema (ou drama) do próprio universo.

A propósito da estética, Antero escreveu: "Sabemos hoje que a estética, sob pena de se excluir sistematicamente da realidade, não pode ser absoluta senão nas suas leis fundamentais, isto é, naquilo mesmo em que é absoluto e imutável o espírito humano; em tudo o mais é, como ele, variável e progressiva. Tem uma estática e uma dinâmica" $\left(^{5}\right)$. Creio que esta observação se deve aplicar à abordagem da sua própria concepção da arte. Há nela uma estática - certos elementos constantes que se afirmam e ganham consistência. Mas esses mesmos elementos consentem uma dinâmica - a dialecticidade interna que, em última instância, é responsável pela profunda evolução do pensamento estético e filosófico do poeta. Captar essa dupla dimensão do pensamento anteriano a respeito da arte é, na verdade, o objectivo que me proponho aqui alcançar.

(4) Carta a Flórido Teles de Meneses, Cartas I, pp. 15-16.

(') Considerações..., Prosas II, p. 210. 


\section{A arte - verdade feita vida}

O primeiro ensaio que merece a nossa atenção leva o título Arte $e$ Verdade. É o único em que Antero fala da arte em geral. Elaborado e redigido no verão de $1861\left(^{6}\right)$, só seria publicado na Revista do Século, no verão de 1865, ainda antes da polémica com Castilho que deu origem aos escritos da "Questão Coimbrã". Deveria constar de duas partes, mas só a primeira, intitulada "O carácter positivo da arte", foi efectivamente publicada $\left({ }^{7}\right)$.

Trata-se de uma celebração enfática e redundante da beleza e da sua forma visível, a arte. Delas se enunciam profusamente os atributos: divindade, santidade, eternidade, imortalidade, perfeição. Outras tantas maneiras de dizer o carácter absoluto da arte, de afirmar o primado da beleza e a sua função mediadora entre as outras duas ideias ou instâncias supremas para a consciência humana: a Ideia (que lhe propõe a ciência ou filosofia) e Deus (que lhe propõe a religião). "O Espírito-diz Antero-realiza-se ali [ na arte] no grau mais subido a que podem chegar as faculdades humanas" $\left({ }^{8}\right)$.

No seu conjunto, o ensaio desenvolve uma concepção classicista e idealizada da arte. Tópico insistente é o da arte como "harmonia" "harmonia eterna", "harmonia superior" - como "síntese" - "síntese harmoniosa" -, como "reconciliação" dos elementos opostos, que podem ser ora "o sonho e a realidade", ora "o pensamento e a paixão", ora "a intuição e a ideia", ora "o coração e a inteligência", ora "a inspiração e o pensamento", ora "o mundo visível e o mundo invisível",

${ }^{6}$ ) Na citada carta a Flórido Teles de Meneses, Antero pede ao amigo que providencie juntodo editorde Miscelânea para arranjar ai um lugar para um seu "estudo sobre a Arte", de que tem já todos os elementos e que só ainda não escreveu por estar adoentado. Na mesma carta esboça o seu pensamento sobre a arte em ternos muito semelhantes aos que usa no ensaio posteriormente publicado.

() Provavelmente Antero tinha intenção de publicar a segunda parte do ensaio. Não o terá feito porque entretanto eclodiu a "Questão Coimbrã", na qual tornou público o seu pensamento estético, dispensando-se a continuação do ensaio. Não é inverosímil que o poeta tenha aproveitado para os escritos da polémica-e também para a Nota final das Odes Modernas - ideias que constituíam matéria da segunda parte do ensaio.

${ }^{8}$ ) Prosas da Época de Coimbra, ed. crítica organizada por António Salgado Júnior, Lisboa, Sá da Costa, 1982, p. 234. 
ora "o universo e a alma", ora "a realidade e o ideal", ora "o espírito e a natureza", ora "Deus e a Ideia", ora, enfim, "a ciência e a religião".

Realizando a harmonia dos contrários e a síntese dos opostos, a arte exibe a "ordem divina" do mundo e exprime a harmonia das faculdades humanas, temperando-as, mas sem as sacrificar umas às outras. Eis uma inspirada formulação desta ideia repetida à saciedade: Entre o sentimento religioso, apaixonado mas confuso e ilusório, e a ciência, luminosa e segura mas fria, há uma região serena e clara aonde a transparência do ar consente aos olhos do espírito perceber na correcção inteira de suas linhas, a forma puríssima da verdade, sem que por isso o coração bata com menos força, sem que por isso deixe de crer, de amar e de ser vivo" $\left({ }^{9}\right)$.

Descontada a retórica, parece que estamos a ouvir o Kant da Crítica do Juizo, ou o Schiller das Cartas sobre a educação estética do homem!

De inspiração classicista é também a concepção da arte como harmonia entre o mundo objectivo e o mundo subjectivo, como feliz acontecimento que ocorre "quando a luz que sai dos factos e a luz que sai da alma (...) se encontram e se fundem" $\left({ }^{10}\right)$. Nesse sentido, a arte é tanto a revelação da natureza no e pelo pensamento, como é a revelação do pensamento na e pela natureza: "é a natureza penetrada, revelada pelo pensamento: é o pensamento tomando, para se revelar, os trajes luxuosos e opulentos da natureza" $\left({ }^{11}\right)$.

Classicista é, enfim, o humanismo estético que emerge nos últimos parágrafos do ensaio. A arte, expressão do homem por excelência, obra sua própria, é "criação livre e consciente", mediante a qual ele ergue um "mundo novo" só seu, uma "nova criação" capaz de rivalizar com a natureza, obra da criação de Deus. Pela arte, o homem afirma e realiza a sua autonomia e poder criador face à natureza e face a Deus. Por ela se imortaliza e cumpre a sua divindade. Nas palavras de Antero: "A arte é a obra eterna do homem. (...) É a nossa glória: e, em face das leis fatais do uni verso, que só parece criador, erguemo-nos também como deuses e podemos mostrar alguma coisa igual, se não superior - uma criação livre" $\left({ }^{12}\right)$. A mesma ideia noutra versão que acentua o tom prometeico: "So a arte fala do homem e do mundo - e o mundo e o homem, passo

\footnotetext{
( ${ }^{9}$ Ibidem, p. 232.

$\left({ }^{10}\right)$ Ibidem, p. 234.

(1) Ibidem, p. 235.

(12) Ibidem.
} 
a passo, dia a dia, alargam-se, crescem e vão tomando os Céus e os Olimpos, todo o domínio antigo do divino" $\left({ }^{13}\right)$.

Mas Antero propusera-se falar do carácter positivo da arte. E é isso que faz, nas últimas páginas do seu ensaio, descendo da "alta e serena região" ideal a que nos guindara e apontando o íntimo comprometimento da arte com a "verdade", com o "mundo" e com a "vida". "A arte - diz - é a verdade movendo-se no mundo", é "a verdade feita vida" $\left.{ }^{14}\right)$. Ela tem a sublime função de interpretar o "símbolo complexo" que é o universo, de revelar o "mistério que o homem busca através das tempestades e das correç̧ões do mundo" $\left({ }^{15}\right)$. Esse mistério - "o sol eterno da verdade", em torno do qual a alma humana gira - tem um nome e este é ainda a beleza.

Não é possível, pois, tomar a arte por um "jogo estéril" ou um "frívolo brinquedo" para entreter a existência. A arte "é uma missãoe a mais alta:é um sacerdócio - e o mais eterno! (...) A arteé o pontífice espiritual do universo" $\left({ }^{16}\right)$.

Esta relação da arte com a verdade, esta concepção da arte (ou da poesia) como "sacerdócio" não é tema novo em Antero. Expusera-a já, quatro anos antes, numa Nota a propósito do Poeta João de Deus $\left({ }^{17}\right)$. E esse mesmo motivo está no centro da polémica contra Castilho e o academismo tradicional que ele representava. Sobretudo, nesta primeira fase, o discurso anteriano sobre a arte move-se efectivamente num ambiente semânticoe linguístico de inequívocas ressonâncias religiosas. Há, por conseguinte, natural continuidade entre o ensaio que temos estado a comentar, os escritos da "Questão Coimbrã" e a Nota final à 1." edição das Odes Modernas (1865), verdadeiro manifesto da nova estética. Na tese - "A Arte é a Verdade feita Vida" - vai dita, antes de mais a exigência da autenticidade da arte, enquanto nascida da imperativa "voz da natureza e do coração", ao mesmo tempo que vai rejeitada a concepção da arte como mero "ofício" mecânico onde a falta de alma, de inspiração e de ideia é suprida pela imitação de modelos académicos ou pela observância de regras formais $\left({ }^{18}\right)$. Vai dita igualmente a
( $\left.{ }^{13}\right)$ Ibidem, p. 237.
$\left({ }^{14}\right)$ Ibidem, pp. 236 e 238.
(15) Ibidem.
(16) Ibidem, pp. 236-237.
( $\left.{ }^{17}\right)$ Prosas da Época de Coimbra, p. 90.
${ }^{18}$ ) Ibidem. 
necessidade do comprometimento da arte na transformação da sociedade e da humanidade, como força civilizadora e moral por excelência. Não só a "voz da natureza" e a "voz do coração", mas também a "voz da sociedade", as suas aspirações e desejos, devem exprimir-se na forma poética. Este o ambicioso programa que o poeta pretende cumprir com as suas Odes Modernas.

A revolução na arte faz parte e é solidária da revolução global que deve atingir todas as esferas do humano (religião, política, economia). Mas a arte é parte destacada nesse processo global, pois, como vimos, ela exprime e manifesta, melhor do que qualquer outra instância, a totalidade dos recursos anímicos, a integralidade do homem. Se a poesia é a forma mais pura daquelas partes soberanas da alma colectiva de uma época, da sua crença e aspiração, quem melhor do que ela pode dar voz ao "sentir mais fundo do tempo"?

Neste ponto, Antero comunga de ideias largamente difundidas na sua época nos círculos do socialismo e do positivismo e que ele bebeu sofregamente, sobretudo nos escritos de Proudhon, de Renan, de Heine. Entre muitos outros, estes pensadores defendiam, com diferentes matizes e motivações, uma arte de vocação social, contra a concepção da arte pela arte, verdadeira caricatura a que o romantismo tardio reduzira a concepção kantiana do carácter desinteressado (Interesselosigkeit) do juízo estético e a concepção classicista e genuinamente romântica e idealista da arte como absoluto.

Também Antero pretende expulsar do templo da poesia "as vestais literárias do culto da arte pela arte" $\left({ }^{19}\right)$. Mas nele afirmar a missão revolucionária da poesia não significa a incondicional subordinação da arte ao social, ou a sua instrumentalização pela política, posição para que tendem muitos dos seus contemporâneos. Embora mais tarde classifique alguns dos seus poemas desta época como pertencentes ao género da "poesia de combate", a sua posição deve ser entendida no âmbito da inspiração classicista e na do primeiro e mais genuíno romantismo: a saber, como determinada pela urgência da realização da ideia no mundo, pela exigência da reconciliação entre a ideia (o sonho, o desejo) e a realidade, pela aspiração à totalidade orgânica a que os românticos haviam justamente chamado Vida.

$\mathrm{O}$ melhor socialismo e positivismo viveram ainda deste sonho e

(19) Prosas I, Coimbra, Imprensa da Universidade, 1923, p. 314. 
apenas pretenderam accionar e urgir os meios eficazes para que ele se tornasse realidade. A Justiça - objectivo que o verdadeiro poeta deve agora servir - é a maneira de dizer o restabelecimento da harmonia no domínio das coisas humanas.

$\mathrm{Na}$ verdade, é a elevada consciência da dignidade e carácter absoluto, não a convicção da subalternidade instrumental da arte, o que leva Antero a afirmar a sua missão revolucionária. Nisso, aliás, professa a sua crença na força da ideia e do espírito, enquanto efectivos condutores do mundo e da história. Assim o escreve: "A literatura, porque se dirige ao coração, à inteligência, à imaginação e até aos sentidos, toma o homem por todos os lados; toca por isso em todos os interesses, todas as ideias, todos os sentimentos; influi no indivíduo como na sociedade, na família como na praça pública; dispõe os espíritos; determina certas correntes de opinião; combate ou abre caminho a certas tendências; e nãoé muito dizer que é ela quem prepara o berço aonde se há-de receber esse misterioso filho do tempo - o futuro" $\left({ }^{20}\right)$.

Quanto ao poeta, Antero exige dele todo o conjunto das qualidades intelectuais e estéticas. Mas acima de tudo exige-lhe as qualidades morais: a dignidade, a virtude, o carácter moral $\left({ }^{21}\right)$. É ele o profeta, requisitadopela "hora da história", que lêo sentido desta noemaranhado caótico dos acontecimentos; é o guardião das ideias, que dá testemunho do espírito e da consciência humana triunfando da matéria; é o sacerdote e o apóstolo que, em tempo de descrença, cepticismo e abaixamento moral, aviva e alimenta a crença nos ideais superiores do homem; é o demiurgo do futuro, o modelador da própria humanidade. Dele depende o destino do espírito das nações, a corrupção ou a grandeza das épocas $\left({ }^{22}\right)$.

Antero, o poeta, não carecia do suplemento da acção política ou social para se poder sentir realizado como homem e como cidadão, para considerar cumprida a sua vocação activa. Mais fundo que o programa político, mais longe que o fusil, alcança o dardo do poema.

$\left({ }^{20}\right)$ A dignidade das letras e as literaturas oficiais, Prosas da Época de Coimbra, p. 308.

(21) Bom senso e bom gosto, Prosas da Época de Coimbra, p. 286.

$\left.{ }^{(22}\right)$ A dignidade das letras..., Prosas da Época de Coimbra, p. 301. 


\section{Historicidade, ocaso e morte da arte}

A Nota final às Odes Modernas contém dois princípios que o seu autor via ligados pela força de um silogismo: "Partindo deste princípio - a Poesia é a confissão sincera do pensamento mais íntimo de uma idade - (...) havia de necessariamente concluir com esta outra afirmação - a Poesia moderna é a voz da Revolução-porque revolução é o nome que o sacerdote da história, o tempo, deixou cair sobre a fronte fatídica do nosso século" $\left({ }^{23}\right)$.

Parecendo ser a extrema exaltação da poesia e da sua missão civilizadora, esta apaixonada Nota é, de facto, o canto de cisne pela poesia e pela arte. Ela anuncia já a iminência daquilo a que, muito mais tarde, o poeta chamará a "condenação da poesia pelo inexorável destino da história" $\left.{ }^{24}\right)$. O mesmo "tempo", que agora requisita o canto do poeta, há-de calá-lo, dispensá-lo ou expulsá-lo, quando a sua voz não for capaz de dizer o sentir íntimo da época que se avizinha.

O segundo grande momento da reflexão anteriana sobre a arte desenvolve-se por um espaço de 15 anos, desde o rescaldo da "Questão Coimbrã" até ao início da década de 80. Quatro ensaios têm a arte ou alguma das artes por tema explícito e, apesar das diferenças, revelam uma preocupação teórica comum. São eles: $O$ futuro da música (1866), Tendências novas da poesia contemporânea (1871), Considerações sobre a filosofia da história literária portuguesa (1872) e A poesia na actualidade (1881).

A meditação anteriana move-se agora cada vez mais no âmbito de um aprofundamento da consciência da historicidade do espírito humano e das suas instituições e realizações. A arte é encarada numa perspectiva histórica como uma das formas mais qualificadas em que se exprime a alma de um povo ou o espírito de uma época. Mas o que o poeta pretende, com a aplicação daquilo a que chama o "método histórico" ${ }^{25}$ ) às realizações literárias e artísticas do passado ou contemporâneas, é traçar o diagnóstico da consciência moderna, que considera moribunda, e perscrutar os sinais do tempo novo que se

\footnotetext{
$\left({ }^{23}\right)$ Prosas I, p. 306.

(24) Carta a António Molarinho, de 26 de Agosto de 1889, Cartas II, p. 952.

$\left.{ }^{25}\right)$ Considerações..., Prosas II, p. 210.
} 
aproxima. Trata-se de saber como é que a arte ou uma dada arte exprime o sentir, a alma de uma dada época e, em particular, trata-se de indagar qual o lugar da arte ou da poesia na época cujo perfil vê erguer-se já no horizonte.

Para esta meditação o poeta vai equipado antes de mais com os pressupostos da filosofia hegeliana da arte e da história. Desta filosofia da história, que para Antero representava não apenas uma parte fundamental da filosofia, mas "quase a filosofia toda" $\left({ }^{26}\right)$, constava, para além da ideia da "evolução psicológica da humanidade" $\left({ }^{27}\right)$, a ideia de que, tanto no seu conjunto como em cada um dos seus momentos, a história é um todo orgânico e vivo. Mas também cada época constitui uma totalidade orgânica e viva, a que preside um princípio interior, que se manifesta nas instituições, na filosofia, na religião e teologia, na arte, nas formas de organização social, política e jurídica. Compreender a história é identificar esse princípio ou "espírito da época", que anima cada momento da história, é reconhecer o modo como ele se explicita. Desta tese decorre uma outra, a saber, que a cada época histórica, como "a cada momento da alma humana corresponde, como expressão completa dela, uma forma diferente da Arte" $\left({ }^{28}\right)$.

É por isso que a arte pode constituir um ponto de vista privilegiado para ter acesso à alma de toda uma época. Pode mesmo acontecer que seja a arte, ou uma dada arte, a mais genuína expressão da alma de uma idade. E pode igualmente dar-se o caso de que uma dada arte ou a arte em geral se revelem incompatíveis com o espírito e o sentir de certas épocas da história, o mesmo é dizer com certos momentos da evolução da consciência humana.

São estas conviç̧ões que presidem ao ensaio intitulado $O$ futuro da música. A tese fundamental aí desenvolvida é a seguinte: a música não ésó a arte que corresponde ao estado de desenvolvimento da consciência na época moderna (séculos XVI-XIX), mas é a expressãopor excelência da alma e pensamento modernos. Há uma relação necessária e íntima entre a música e a modernidade, que faz com que aquela reproduza e exprima as características essenciais e originais do espírito moderno.

\footnotetext{
(26) Carta de 28 de Junho de 1874 a Jaime Batalha Reis, Cartas I, p. 247.

$\left({ }^{27}\right)$ A poesia na actualidade, Prosas II, p. 318.

${ }_{\left({ }^{28}\right)}$ O futuro da música, Prosas da Época de Coimbra, p. 266.
} 
E quais são estas características?

Segundo Antero, o espírito moderno caracteriza-se pela exacerbação do sentimento e pela flutuação e contradição dos sentimentos. É um "espírito cheio de esperança e vazio de crenças, alimentando de sonhos um infinito desejo de realidades, tristes até à morte, alegre até ao frenesi, atrevido, intemerato - e desolado" $\left({ }^{29}\right)$. O espírito moderno vive a contradição íntima entre o sentimento da ilimitada liberdade e o sentimento da mórbida melancolia: "junto com a ambição ilimitada, um doloroso sofrimento, uma fraqueza mórbida, uma vaga e indefinível doença, (...) a coisa essencialmente moderna enfim, o sentimento, a melancolia" $\left.{ }^{(30}\right)$. Quem se não a música poderia exprimir adequadamente esta permanente flutuação de sentimentos? A música, dissera-o já Kant e repeti-lo-iam os românticos, é a "linguagem dos sentimentos" ( $\left.{ }^{31}\right)$; ela é, como mostrara Hegel, toda subjectiva; nela, o subjectivo - o sentimento - é a matéria e a forma ao mesmo tempo $\left({ }^{32}\right)$.

Não podemos deter-nos na análise desta interpretação anteriana da modernidade, a qual pode considerar-se como uma interessante modulação do tema hegeliano da consciência infeliz. A modernidade é um mal-estar instalado na consciência, uma consciência que se sabe doente e que é incapaz de se curar; é "o imenso mal secreto das almas, a tristeza, a melancolia" $\left({ }^{33}\right)$.

O diagnóstico revela, portanto, a doença mortal, o esgotamento e morte da consciência moderna consumada no romantismo. $\mathrm{O}$ fim da modernidade e do romantismo é, assim, tambẹm o fim e morte daquilo que exprimia a sua alma, a música, "a arte romântica por excelência" $\left({ }^{34}\right)$, que, para os românticos, era igualmente a própria essência da arte.

Se Antero se demorou a fazer o diagnóstico da modernidade e a identificar o seu espírito e expressão próprios, foi para fazer o balanço da sua própria formação intelectual e chegar a compreender melhor a sua própria alma, também ela doente e, tal como a humanidade

\footnotetext{
$\left({ }^{29}\right)$ Ibidem, p. 269.

$\left({ }^{30}\right)$ Ibidem, p. 268.

( $\left.{ }^{31}\right)$ Kant, Kritik der Urteilskraft \$ 53, Akademie Ausgabe, Berlin, vol. V, p. 328.

(32) Hegel, Vorlesungen über die Ästhetik, Sämtliche Werke, Jubiläumausgabe, Stuttgart-Bad Cannstatt, 1971, vol. 14, p. 127.

$\left({ }^{33}\right)$ O futuro da música, Prosas da Época de Coimbra, p. 270.

(34) Ibidem, p. 278.
} 
moderna, "orfã de todos os deuses" $\left({ }^{35}\right)$. Foi, enfim, para estabelecer o contraste com o espírito e feição da nova época que já se anuncia, cujas características são o oposto de tudo aquilo que a música representava. $O$ futuro, diz Antero, pertence à confiança, a uma verdade qualquer, não à flutuação. Fixar o desejo, determinar a realidade, fixar a crença e os sentimentos - eis o que exige agora o espírito humano. E de quem espera ele essa tarefa? E qual o princípio que há-de inspirar a nova ordem das coisas e gerar uma nova filosofia, uma nova política e até uma nova poética?

O positivismo junta-se agora ao hegelianismo de fundo para dar resposta a estas questões: "Nas mãos da ciência está o molde; ele só fundirá a estátua da futura sociedade. (...) A análise, a reflexão, a ciência, eis aí o verbo novo. A consciência, na sua constante evolução, passou do estado intuitivo, maravilhoso, para uma fase superior, reflectida, eminentemente positiva e naturalista. Do sentimento subiu-se à razão: e é dela que se espera agora tudo quanto se estava acostumado a pedir ao vago pressentimento, às intuições sublimes mas ilusorias" ( $\left.{ }^{36}\right)$. A tarefa agora é "organizar o mundo humano em oposição com as idades religiosas e intuitivas, sobre a base exclusiva da razão e da experiência" ${ }^{37}$ ).

E que será da arte num mundo organizado pela ciência?

Esta questão formularam-na também muitos contemporâneos de Antero, que, tal como ele, combinavam os princípios do hegelianismo com a nova crença positivista. A tese hegeliana da morte da arte e da sua necessária superação pela filosofia é vertida na tese da superação da arte pela ciência positiva, de que resultará ou uma nova arte realista, ou mesmo o desaparecimento inevitável da arte $\left(^{\mathbf{3 8}}\right)$.

Antero acreditou sinceramente que a ciência não só traria uma nova forma de arte, mas que essa arte seria superior a todas as conhecidas. Regida pela razão, tal arte caracterizar-se-ia pela rigorosa adaptação à realidade, pelo equilíbrio entre o desejo e o possível, pelo estreitamento progressivo dos domínios da fantasia, da imaginação, do sonho, da intuição, pela acalmia dos sentimentos, pela contenção da paixão, pela

$\left({ }^{35}\right)$ Ibidem, p. 270.

(36) Ibidem, p. 275.

${ }^{(37}$ Ibidem.

${ }^{38}$ Cf. Simón Marchán Fiz, La Estética en la Cultura Moderna, Madrid, Alianza Editorial, 1987, p. 182. 
mesura do entusiasmo e serenidade dos afectos. Ou seja: pelo geral império da faculdade racional sobre as faculdades intuitivase afectivas. Todo um programa de uma poética do realismo e naturalismo!

Mas, ao resolver os problemas científicos, políticos e morais que afligem os humanos, a ciência elimina as próprias condições que poderiam favorecer as manifestações poéticas e artísticas: "Resolvidos os problemas, cuja incerteza mais nos angustia, uma confiança maior e uma crença descansada nas leis do universo tomarão naturalmente o lugar desta ânsia angustiosa, desta dolorosa instabilidade, que tanto oprime o sentimento contemporâneo. Postos os espíritos no estado de equilíbrio moral que se chama crença, e, por outro lado, assente a sociedade nas bases da justiça e da verdade, deixarão de pungir os corações os dois mais agudos espinhos, o cepticismo e a desigualdade, nos dois lados mais sensíveis e doridos, o sentimento religioso e o sentimento da justiça. Como consequência de todas estas condições de harmonia e fixidez ver-se-á a alegria e a serenidade consolar o mundo da palidez destes nossos tempos de melancolia e de dúvida. Chorar-se-á menos; já pelo desaparecimento de muitos motivos de desgosto; já pela disposição interior dos homens, mais ligados com a realidade e menos inclinados à paixão e ao desespero" $\left({ }^{39}\right)$.

Que longe estamos do autor de $O$ sentimento da imortalidade e de Arte e Verdade! Aí, uma lágrima dizia mais do que um silogismo, o sentimento continha mais verdade do que a razão e toda a sua ciência e filosofia. À beleza è arte é que se reconhecia a função de reconciliar os opostos, de criar a harmonia, de exprimir a "ordem divina" do mundo.

As mesmas preocupações e questões dominam o ensaio de 1871, intitulado Tendências novas da poesia contemporânea. Testemunha-se aqui a morte e a justa condenação do romantismo e do seu falso princípio poético-a sentimentalidade, diz Antero. A missão da poesia, diz Antero, "É essencialmente positiva, social e racional, e o romantismo era essencialmente apaixonado, individual e subjectivo. Por mais que se virasse para o futuro, a sua alma pertencia ao passado" $\left({ }^{40}\right)$.

Antero reconhece, por certo, que, na hora presente, "a ideia poética acha-se confusa, embaraçada no meio de factos sociais, que se não

$\left({ }^{39}\right)$ O futuro da música, Prosas da Época de Coimbra, pp. 276-277.

${ }^{\left({ }^{40}\right)}$ Prosas II, p. 194. 
definem claramente: as fontes da inspiração correm escassas ou turvas" $\left({ }^{41}\right)$. Mas continua convencido de que a sociedade contemporânea, fundada sobre "a ciência friamente analítica", não só não é anti-poética, como trará mesmo consigo uma ideia de "poesia nova" que será "superior à ideia poética das épocas anteriores, porque corresponde a um período mais adiantado da consciência humana, penetra com maior intensidade a natureza e o espírito, extrai o belo da própria realidade universal, não das visões de um subjectivismo inexperiente, e dá por base ao sentimento, em vez de sonhos e intuições quase instintivas, os factos luminosos da razão" $\left({ }^{42}\right)$. E prossegue, apontando os caracteres essenciais dessa nova poesia, que "todos eles se consubstanciam numa palavra, que resume também as tendências da nossa civilização: o Humanismo" $\left({ }^{43}\right)$. Essa nova poesia , é em todos os aspectos, a antítese da poesia romântica: "A inspiração social e naturalista vem substituir a sentimentalidade toda subjectiva e pessoal, ou o transcendentalismo contemplativo de outras idades poéticas. A poesia deixa de duvidar e cismar, para afirmar e combater; mostra-nos o interesse profundo e o valor ideal dos factos de cada dia; dá às acções, que parecem triviais, da vida ordinária, um carácter e significação universais" $\left({ }^{44}\right)$.

Mas tanto a crença na capacidade da ciência para erguer uma civilização que satisfaça as exigências da consciência humana, como a crença na possibilidade de a mesma ciência positiva dar origem a uma nova arte e poética vão entrar definitivamente em crise. Por vezes, é negando as evidências e pronunciando um voluntarioso credo quia absurdum que Antero continua a pensar nessa possibilidade muito remota $\left({ }^{45}\right)$. Ou então é esperando que a magia da dialéctica histórica consiga engendrar a sua própria antítese $\left({ }^{46}\right)$. Cada vez mais, porém, se torna manifesta a crise geral da civilização ocidental, para a qual o poeta não vê retorno nem solução, a não ser, como veremos, por uma regeneração moral.

Enfim, Antero acaba por concluir que a ciência não pode gerar o seu
$\left({ }^{41}\right)$ Ibidem, p. 195.
(42) Ibidem, p. 196.
$\left({ }^{43}\right)$ Ibidem, p. 197.
$\left({ }^{44}\right)$ Ibidem.
$\left({ }^{45}\right)$ Cf. Cartas II, pp. 952-953.
$\left({ }^{46}\right)$ Cartas II, pp. 871, 879. 
contrário: um símbolo plástico, uma intuição poética. E, segundo ele mesmo confessa, essa convicção impôs-se-lhe por "um estudo mais profundo da filosofia da história", que lhe mostrou "o verdadeiro processo da evolução psicológica da humanidade" $\left({ }^{47}\right)$.

Efectivamente, o ensaio intitulado $A$ poesia na actualidade (1881) propõe uma filosofia da história da arte e da sua relação com as faculdades humanas, na qual se reconhece a inspiração das teses da Scienza Nuova de Vico $\left({ }^{48}\right)$, ao mesmo tempo que procede a uma análise da situação contemporânea da poesia em alguns dos seus expoentes maiores: Heine, Baudelaire, Edgar Poe.

O ensaio abre com este duro prognóstico, verdadeira declaração de morte anunciada da arte e da poesia: "A fase poética da Humanidade pode dizer-se que está a terminar. Este século terá visto os últimos poetas, como viu os últimos crentes. O espírito humano entrou decididamente numa fase de racionalismo, de análise e crítica, que parece dever ser definitiva" $\left({ }^{49}\right)$.

O filosofo da arte divide agora a história em duas fases: a fase poética e a fase positiva. A primeiraé dominada por aquilo a que chama a "faculdade sintética" ou "faculdade criadora" ("poder criador e sintético"), a cujo trabalho atribui a origem das línguas, dos mitos, das religiőes e da poesia $\left({ }^{50}\right)$. A fase positiva é dominada pela faculdade analítica e crítica, ou seja, pela razão, e o seu produto é a ciência.

A poesia nasce quando à intuição, espontânea e instintiva quando cria as línguas e os mitos, se junta a reflexão. Por isso, a poesia representa a síntese entre a pura espontaneidade da intuição e a pura reflexão, o equilíbrio entre o domínio absoluto da síntese e o domínio absoluto da análise. Nessa posição intermédia tem por solidárias companheiras a metafísica e a teologia. Há entre elas um ar de família que indica a comum origem. A fase poética da humanidade pode, pois, chamar-se com mais propriedade o seu "período poético-metafísico-teológico". É um período caracterizado pela ponderação, colaboração

( $\left.{ }^{47}\right)$ A poesia na actualidade, Prosas II, p. 318.

${ }^{48}$ Vico defendera a existência de uma fase poética da humanidade, com autonomia e coerência próprias, com a sua metafísica, a sua lógica, a sua moral. Cf. Principi di Scienza Nuova (ed. 1744), Milano, Rizzoli Editore.

( $\left.{ }^{49}\right)$ Prosas II, p. 310.

( ${ }^{50}$ ) Esta ideia estava já indicada no ensaio Espontaneidade, Prosas da Época de Coimbra, p. 260. 
e harmonia das faculdades analítica (razão) e sintética (intuição), e que historicamente se estende desde Homero ao primeiro quartel do século XIX.

Dentro desse período Antero distingue três momentos principais: o do idealismo poético transcendental dos gregos, todo vasado em moldes simbólicos e caracterizado por um humanismo espontâneo; odo racionalismo formal mas poético da Idade Média, onde o sentimento e o delírio se escondem sob as apertadas malhas do sistema escolástico; o naturalismo idealista, poético e místico, do Renascimento, onde os sentimentos naturais do homem se expõem livres e em toda a sua pujança.

Neste quadro, o romantismo não constitui propriamente um momento novo, mas é apenas um "rebento tardio", que, com o anúncio do seu fim próximo, anuncia também o fim do período poético da humanidade $\left({ }^{51}\right)$.

Lançando o olhar à situação da poesia no seu tempo, Antero só via confirmado o veredicto de extinção e morte. Ela "deixou de ter missão social", perdeu o antigo carácter de grande força social e espiritual da humanidade. $O$ que dela existe é relegado para a categoria da "literatura amena", ou da expressão isolada de sentimentos muito pessoais daqueles que "reagem contra a tirania da reflexão e tendem a isolar o seu mundo de sentimentos da influência mortal do espírito analítico e positivo" $\left.{ }^{(52}\right)$. E que é ela, aliás, mesmo nos maiores representantes do

${ }^{(51)}$ A poesia na actualidade, Prosas II, pp. 317-318. As críticas de Antero ao romantismo não conseguem apagar o profundo traço romântico da sua poesia $e$ personalidade. $O$ próprio poeta confessava o fundo romântico da sua psicologia, ao dizer a Jaime de Magalhães Lima: "A natureza tinha-me talhado para romântico descabelado, pessimista, satânico, que sei eu? Mas tinha-me dado, ao mesmo tempo, por singular contradição, razão e sentimento moral para muito mais e melhor. Daí conflito, guerra civil, luta interior. Essa luta foi a minha vida, e é o que explica a aparente singularidade (que reconheço ser grande) e a esterilidade dela. $O$ que venceu em mim foi a razão e o sentimento moral; mas a imaginação e a paixão, embora vencidas, não se submeteram. Ora não é a razão, mas a imaginação e a paixão que fazem o poeta. (...)

Um profundo suspiro, um suspiro de infinita doçura mas de infinita melancolia, eis todo o nosso canto." (Carta de 13 de Outubro de 1886, Cartas II, p. 792). A luta contra o romantismo é pois uma luta contra si próprio! Numa outra carta a João Lobo de Moura, de 22 de Agostode 1881, diz: "Oromantismo, contrabalançado pelo misticismo, produz um fluxo, uma acção e reacção, que julgo muito favorável à vida espiritual". (Cartas I, p. 569).

( $\left.{ }^{52}\right)$ Prosas II, p. 322. 
século, num Heinrich Heine, num Baudelaire, num Edgar Poe? Em quadrantes diferentes, em modulações diversas, cada um deles proclama o fim da poesia e de tudo aquilo que ela significa na sua essência. Em Heine, é a sátira amarga, o sarcasmo, a ironia e o riso céptico, em vez da crença; em Baudelaire, é a "prostituição" da poesia que, assim, escarnece da sua própria vocação moral; em Poe, é a poesia como a proclamação do desespero e do amargo cepticismo. "Foi assim - conclui Antero-que a poesia, na segunda metade do século XIX, anunciou ao mundo, a seu modo, praticamente, poeticamente, a sua próxima extinção" $\left({ }^{53}\right)$.

Embora reconhecendo que nisso se cumpre o inexorável destino da história, é com indisfarçável nostalgia da época poética da humanidade (que, afinal, realizou a harmonia que a ciência não alcança), é com um profundo sentimento de melancolia que Antero exara a certidão de óbito da poesia e, como um naturalista, regista a extinção iminente da espécie dos poetas. Estes, os que ainda existem, "são apenas os restos destroçados duma raça de outras idades e que breve terá desaparecido" $\left({ }^{54}\right)$.

Compreende-se melhor, neste contexto, aquilo a que se tem chamado a "morte poética" de Antero $\left.{ }^{(55}\right)$. No fundo, talvez não visse mais razões que valessem e urgissem a forma dum poema. Ou, então, reconhecia agora que "o que o mundo mais precisa, nesta fase de extraordinário obscurecimento da alma humana, é de ideias, é de filosofia - e a Poesia, voltando a adormecer nos recessos mais misteriosos do coração do homem, tem de ficar à espera até que o novo Símbolo se desvende e novos Ideais the forneçam um novo alimento, lhe insuflem nova vida (...) e então voltará a cantar". Porque "o mundo (este mundo) está velho: e a Poesia só está à vontade num mundo novo, jovem, energético" ( $\left.{ }^{56}\right)$. A morte do poeta representaria, neste caso, o despertar do filosofo que por longo tempo dormira em Antero e nele se exprimira sobretudo pelo canto da poeta.

( $\left.{ }^{53}\right)$ Ibidem, p. 320 .

$\left({ }^{54}\right)$ Ibidem, p. 321.

(5s) Cf. Cartas II, p. 872. Cf. José Alves, Antero de Quental. Les mortelles contradictions, Paris, F. C. Gulbenkian, 1982, p. XVII. p. 749.

(56) Carta a Carolina Michaëlis de Vasconcelos, de 7 de Agosto de 1885, Cartas II, 


\section{Acima da literatura, o drama do universo e o poema da existência moral}

A conclusão que se extrai da leitura dos ensaios que acabamos de analisar e que testemunham uma evolução de 15 anos da vida do poeta poderia resumir-se nas palavras com que um filósofo contemporâneo, Theodor Adorno, abre a sua Teoria Estética (1970): "Tornou-se manifesto que tudo o que diz respeito à arte deixou de ser evidente, tanto em si mesma como na sua relação ao todo, e até mesmo o seu direito à existência. (...) O lugar da arte tornou-se incerto. (...) Não se sabe se a arte pode ainda ser possível; se ela, após a sua completa emancipação, não eliminou e perdeu os seus pressupostos" $\left({ }^{57}\right)$.

Estas considerações parecem ter sido escritas com os textos de Antero à vista. Na verdade, porém, o que têm à vista todos os grandes pensadores da morte da arte, desde Hegel a Adorno, é o próprio destino histórico da arte e o modo ambíguo como a consciência se situa em relação a ela.

Para Hegel, a arte $e$ algo absoluto ou, pelo menos, é uma das formas de realização do absoluto na consciência, ao lado da religião e da filosofia; e, todavia, ela tem de ser superada, pois a consciência não pode deter-se nela. O espírito já só pode encará-la como algo "passado" (Vergangenes), como objecto de gozo ou de apreciação, de análise ou de reflexão, mas que deixou de ter "autêntica verdade e vitalidade" $\left({ }^{58}\right)$. A arte morre ou tem de morrer porque já não pode satisfazer as exigências e os interesses da consciência.

Também Antero reconhece que há uma certa justiça da história na condenação da arte e da poesia, pois estas confessam a sua impotência no próprio acto em que prometem e cantam a libertação humana: "A poesia tem embalado, com a sua divina melopeia, as dores da humanidade, tem adormentado o sentimento acerbo das suas inenarráveis misérias: mas essas dores, essas misérias não as pode ela suprimir" $\left({ }^{59}\right)$.

Em suma, a poesia e a arte são um ópio, um narcótico para a

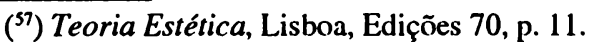

${ }^{\left({ }^{8}\right)}$ Vorlesungen über die Ästhetik, Sämtliche Werke, Jubiläumausgabe, Stuttgart-Bad Cannstatt, 1971, vol. 12, p. 32.

${ }^{(59}$ ) Carta a António Molarinho, Cartas II, pp. 952-953. 
consciência. Quando esta acorda do seu torpor e se assume na sua auto-evidência, deixa para trás a arte, que só lhe dava a feliz realidade sob a forma do sonho e da ilusão. A consciência quer a verdade, a realidade efectiva, a vida autêntica.

Só quem muito investiu na arte, quem muito dela esperou podia ter tão fundo o sentimento da sua radical impotência, da sua incapacidade para corresponder a tanta esperança e satisfazer tanto desejo. Aqueles que a tomam só por uma função decorativa, esses não podem compreender a pertinência duma questão como a da morte da arte. Mas que esta se revele como uma questão insistente na história intelectual dos últimos dois séculos, que ela solicite pensadores que de modo nenhum são dos menores, isso mostra que, aoocupar-se reiteradamente dela, Antero tocava um tão sério quanto doloroso ponto sensível da consciência filosófica do seu (e do nosso) século. A morte da arte diz a morte do absoluto, naúltima figura da sua incarnação, diz a experiência do deserto, diz a erosão do sentido da existência.

Como preenche Antero o vazio especulativo e afectivo deixado pela experiência da morte da arte e da extinção da poesia?

Vimos como ele, com o seu tempo, acreditou ou quis acreditar que a ciência e o seu séquito (a democracia e o progresso) eram capazes de satisfazer completamente as exigências do espírito e da humanidade na nova época que se aproximava. Na verdade, porém, acabou por sofrer nova e dolorosa desilusão. Com efeito, cedo desvanece e morre nele a esperança de que o princípio científico traga, com a solução efectiva dos problemas humanos, também uma nova forma de arte e de poesia, superior à das épocas anteriores. À medida que esse princípio toma conta do mundo material e espiritual, todos os sinais apontam no sentido de evidenciar a absoluta incompatibilidade entre a ciência e a intuição poética.

Mais grave, porém, que a incompatibilidade entre a ciência e a poesia é a incompatibilidade entre a visão científica do mundo e as exigências mais fundas e urgentes da consciência moral. É esta incompatibilidade, manifesta na "formidável antítese determinismo-liberdade" $\left({ }^{60}\right)$, que vai mobilizar todas as energias intelectuais e

$\left(^{(00}\right)$ Tendências gerais da filosofia na segunda metade do século XIX, organização, apresentação e notas de Leonel Ribeiro dos Santos, Lisboa, Editorial Comunicação, 1989, p. 75. 
morais do poeta na última fase da sua vida $\left({ }^{61}\right)$. Efectivamente, durante a década de 80, o pensamento de Antero é marcado pela crescente convicção de que a ciência não pode constituir a última palavra acerca do sentido da existência, acerca do destino da sociedade e da história humanas, acerca do próprio universo. A visão mecânica e fria que ela propõe tem de ser integrada numa visão superior que tenha em conta, antes de mais, as incontornáveis exigências da consciência moral.

Chamo a esta visão superior uma visão moral do mundo, pois que o princípio que a inspira é o do primado absoluto da vida moral e o seu propósito é o de reconciliar, numa grandiosa síntese que satisfaça a razão e o sentimento, tanto a consciência do homem como o universo, unidos num solidário destino de progressiva libertação e espiritualização. A virtude, a santidade, a liberdade moral, numa palavra, o Bem, eis para onde tende toda a evolução do universo e todo o progresso da humanidade $\left.{ }^{\left({ }^{2}\right.}\right)$. Neste novo contexto, não só a ciência e visão científica do mundo, mas também a literatura, a poesia e a arte vão adquirir uma dimensão relativa.

Antero não voltará a ocupar-se expressamente da arte ou da poesia, mas algumas das cartas desta fase dão-nos claras indicações do seu pensamento a esse respeito. Numa, datada de 22 de Janeiro de 1882 , dirige-se a Joaquim Araújo, nestes termos: "Não lhe digo que não faça literatura; mas ponha acima da literatura alguma coisa, o que é vital, real, o que abraça a vida e o seu fim moral, e não só a imaginação e uma inteligência apenas abstracta. $O$ nosso verdadeiro poema somos nós mesmos, quero dizer, a nossa vida moral, que é a obra suprema do Universo" ${ }^{\left({ }^{63}\right.}$. No mesmo registo dirá a Carlos de Lemos: "Fazer-se homem (...) é esse o fim soberano da vida, e arte, ciência, filosofia seriam vãs, se não fossem meios e instrumentos para esse fim. Se a arte é coisa sagrada, é-o só por este título" ${ }^{(64)}$.

E é ainda a mesma ideia, agora curiosamente associada à fórmula kantiana da arte como símbolo da moralidade, que encontramos numa carta de 1889, dirigida ao poeta António Molarinho, nestes termos: "Pense que a arte, por bela e sedutora que seja, não é ainda assim mais

\footnotetext{
('1) Cf. Carta a W. Storck, de 14 de Maio de 1887, Cartas II, p. 838.

( ${ }^{62}$ Ibidem.

${ }^{(63)}$ Cf. Cartas II, pp. 616 e 701.

(4) Cartas II, p. 867.
} 
do que um reflexo, um símbolo do ideal supremo da vida moral, e que esse ideal, subsistente em si e por si, não precisa de formas, caducas afinal ainda as mais esplêndidas, para se afirmar, pois o que é tira-o de si, da sua substância inesgotável, espiritual, infinita. (...) Creia que a virtude pode e é mais que a arte e dura mais também: dura eternamente. (...) $\mathrm{O}$ universo só dura pelo bem que nele se produz. Esse bem é às vezes poesia e arte. Outras vezes é outra coisa. Mas no fundo é sempre o bem e tanto basta $\left({ }^{65}\right)$.

A receita que dava aos amigos e correspondentes aplicava-a Antero em si mesmo, organizando todo o seu mundo de sentimentos e de ideias em torno do novo centro. Da consciência moral lhe vinha o pouco de luz que iluminava o "paradoxo universal das coisas" e o permitia decifrar como um "divino paradoxo" $\left({ }^{66}\right)$. E agora que sente que o abandonam a inspiração poética e a "espontaneidade criadora" $\left({ }^{67}\right)$, movido por uma última urgência do seu espírito ávido de sentido, mas já com a serena lucidez duma consciência apaziguada, entrega-se à tarefa de erguer o grande poema do universo.

Da estrutura e da lei interna desse poema fala sobretudo o seu ensaio filosófico mais significativo, Tendências gerais da filosofiana segunda metade do século XIX (1890). Expõe-se aí o universo evoluindo espontaneamente, desde as formas mais elementares da matéria para a complexidade da vida, enfim para a consciência, a liberdade, o espírito. Mas esta poética do mundo, servida pela linguagem da dialéctica hegeliana e do expressionismo monadológico leibniziano, tem a sua contrapartida numa poética do espírito de clara inspiração kantiana. Não me refiro apenas às reiteradas afirmações acerca do primado da vida moral, mas também ao reconhecimento do trabalho do espírito sobre si próprio e sobre o universo, a consciência de que "o espírito é o ser tipo, a medida de todos os seres, revelação da sua mais íntima natureza" $\left.{ }^{68}\right)$. É partindo do espírito que se há-de conhecer o mundo, e não o inverso. Pode, por isso, dizer-se que, no fundo, o universo é uma "criação do espírito" $\left.{ }^{69}\right)$. É-o já no plano da compreensão cien-
${ }^{(65)}$ Cartas II, pp. 952-953.
( ${ }^{66}$ ) Cartas II, p. 842.
$\left({ }^{67}\right)$ Cartas II, p. 872.
${ }^{68}$ Tendências, ed. cit., p. 48.
${ }^{(69}$ Ibidem, p. 71. 
tífica das suas leis, que são as mesmas leis do espírito. Mais decisivamente, porém, é ainda no espírito humano, na lei da sua consciência moral, que a existência humana e o universo encontram a chave do seu enigma. Como já o dissera o jovem pensador, o nada não pode ser o termo da existência: "uma negação não pode ser o último verso do poema dos destinos" $\left({ }^{0}\right)$. Em verdade, o "drama divino do universo" consuma-se e decifra-se no poema da existência moral, e este escreve-se com a virtude, a renúncia ao egoísmo, a santidade.

As últimas páginas das Tendências expõem, com inexcedível eloquência, esta dimensão universal, cósmica e ontológica da realização moral do homem, mesmo individualmente considerado. Demos então a palavra ao poeta: "O bem é o momento final e mais íntimo da evolução do ser. (...) A virtude, liberdade suprema, é a realidade por excelência, a única realidade plena. (...) Se pois só a perfeita virtude define completamente a liberdade, e se a liberdade $́$ a aspiração secreta das coisas e o fim último do universo, concluamos que a santidade é o termo de toda a evolução e que o universo não existe nem se move senão para chegar a este supremo resultado. O drama do ser termina na libertação final pelo bem" $\left.{ }^{(11}\right)$.

Em face disto poderíamos ser levados a concluir que o poeta-sacerdote-missionário de outrora perdeu a sensibilidade para a arte e a poesia. Mas não. É justamente agora que ele se revela mais apto para criticar a instrumentalização da arte para fins extra-artísticos e para recuperar o genuíno sentido da autonomia da arte. É assim que, olhando retrospectivamente para a sua poesia dos anos de juventude, na qual muitas vezes o panfletário se divisa por detrás do poeta, ele reconhece que "essa poesia de combate, revolucionária e declamatória" é, poeticamente falando, um "género falso" $\left({ }^{2}\right)$.

A dolorosa experiência da morte da arte teve nele o efeito de uma ascese purificadora, levando-o a descobrir que a arte autêntica é desinteressada e serena, é a "contemplação pura das coisas". Tal a convicção que expõe, na apreciação da terceira versão do romance de Eça - O Crime do Padre Amaro, numa bela página que revela bem a

$\left({ }^{70}\right)$ O sentimento da imortalidade, Prosas da Época de Coimbra, p. 251.

(71) Tendências, p. 84. Cartas II, p. 838.

$\left({ }^{72}\right)$ Cartas II, pp. 671 e 837. 
faceta do poeta e do filosófo enquanto crítico literário. Depois de felicitar Eça por ter refundido a sua obra, que considera agora "perfeita" e um "exemplar de psicologia social portuguesa contemporânea", Antero sublinha a pureza genuinamente estética do resultado, nestes termos: "Aquilo não é realismo, nem naturalismo, nem Balzac, nem Zola: aquilo é a verdade, a natureza humana, que é o que faz as obras sólidas, não os sistemas, as escolas. O outro Amaro está muito longe disto: além das tendências literárias visíveis, havia as tendências voltairianas, uma espécie de hostilidade do autor contra os personagens, que ele descrevia com intenções extra-artísticas; para concluir, para provar tese. Agora é outra coisa. Agora está V. na região serena da contemplação pura das coisas, cheio de longanimidade, imparcial, vendo só os homens e os corações dos homens, pelo interesse que neles há, pela verdade natural, e não como argumentos para teses. Isto, quanto a mim, é o que é verdadeiro realismo, verdadeiro naturalismo, isto é que é a grande Arte. (...) A grande arte é sempre serena, tolerante, magnânima" $\left({ }^{3}\right)$.

\section{Antero, poeta do pensamento}

Recapitulando o percurso até agora feito, verificamos que há, na evolução do pensamento de Antero a respeito da arte, três fases bem distintas.

A primeira, caracterizada pela retórica abstracta, mas sincera e generosa, em que se combinam, melhor ou pior, as matrizes do classicismo, do romantismo, do idealismo e do humanitarismo proudhoniano. A arte $e$ intensamente celebrada como agente e ingrediente essencial da acção de transformação global da sociedade. Não há aí verdadeira distinção entre a acção da palavra poética e a acção política revolucionária. Mas a revolução que a arte serve é uma revolução de feição mais moral e civilizacional do que política ou social.

A segunda fase é marcada por sucessivas crises nas conviç̧ões e ideais fundamentais do poeta. É a fase da fé na ciência, na democracia, no progresso e na história. Mas também a fase das profundas depressões

$\left({ }^{73}\right)$ Cartas I, pp. 499-500. 
(que certamente não tiveram só causas teóricas, mas também causas sócio-culturais, psicológicas e biológicas), docepticismoe pessimismo, da experiência do grande vazio da existência e da falta de sentido num mundo petrificado e gelado pela ciência. $O$ pensador ganha em ponderação e poder de análise. O seu pensamento filosófico e estético nutre-se da análise histórica e caracteriza-se justamente pelo profundo sentido da historicidade da consciência humana e das suas realizações. O hegelianismo e o positivismo, sobretudo através dos epígonos destas tendências filosoficas, constituem as referências teóricas fundamentais. Antero percebeu, desde 1866, que a "filosofia do futuro" poderia bem ser a síntese dessas duas matrizes de pensamento, e é esta intuição juvenil que vai desenvolver ainda nas Tendências $\left({ }^{4}\right)$. A concepção anteriana da arte é nesta fase dominada pela consciência do seu carácter epocal e finito, e pelo reconhecimento de que o mundo futuro não pode ser organizado pela arte, mas pela ciência. A morte da arte, reconhecida como um destino histórico, é vivida pelo poeta com um cada vez mais indisfarçável sentimento de melancolia.

A terceira fase é a do Antero da maturidade intelectual e da serenidade sentimental reencontrada. O poeta revê em profundidade as suas referências filosoficas fundamentais. As influências recebidas são-no agora de uma forma muito mais autónoma e cada vez se adverte mais o trabalho pessoal de síntese. Hegelianismo, leibnizianismo e kantismo são, entre muitas outras, onde sobressai a filosofia de Eduard von Hartmann, as referências maiores da nova síntese anteriana. Esta tem por impulsionador o aguilhão do sentimento ou a voz da consciência moral e expõe-se sob a forma de uma grandiosa visão moral do mundo humano e natural, de inegável acento místico e religioso.

Como ler esta evolução, esta sucessiva deslocação de centro de referência?

Não se trata de mera instabilidade emocional ou diletantismo filosofico. Não se trata sequer apenas de um problema peculiar de Antero, determinado pelo seu temperamento. Como deixámos suficientemente indicado, a contradição estava na consciência da época. Antero teve a sorte ou a desgraça de pertencer ao número daqueles que, por terem o ouvido encostado ao coração do seu mundo e do seu

(74) Cf. O futuro da música, Prosas da Época de Coimbra, p. 276. 
tempo, a sentiram na sua própria consciência. Mas nessa condição não esteve só. Alguns dos melhores espíritos do tempo passaram por uma evolução análoga, como é, nomeadamente, o caso de Heine $\left({ }^{75}\right)$.

De Antero, se não nos podem servir hoje as soluçð̃es filosóficas, morais ou estéticas, resta-nos o humano testemunho da sinceridade de um espírito que em nenhum momento fugia às contradiçães ou aos paradoxos, mas sempre, como confessa, "interrogava com a seriedade e a energia de quem, antes de morrer, quer ao menos saber para que veio ao mundo" $\left({ }^{76}\right)$. Nele, a vida sempre comanda o pensamento e o sentimento sempre se insinua ainda nos mais austeros raciocínios. Foi um pensador da arte e da poesia. Foi também um poeta do pensamento.

$\left({ }^{75}\right)$ Sobre este ponto, v. Rita Iriarte, "A concepção estética e política da literatura em Heinrich Heine", Revista da Faculdade de Letras (Lisboa), IV Série, 1876/77, pp. 201-220.

$\left({ }^{76}\right)$ Cartas II, p. 838. 